Relations industrielles

Industrial Relations

\title{
A World-wide Economy
}

\section{Lionel Moreau}

Volume 6, numéro 3, juin 1951

URI : https://id.erudit.org/iderudit/1023225ar

DOI : https://doi.org/10.7202/1023225ar

Aller au sommaire du numéro

Éditeur(s)

Département des relations industrielles de l'Université Laval

ISSN

0034-379X (imprimé)

1703-8138 (numérique)

Découvrir la revue

Citer cet article

Moreau, L. (1951). A World-wide Economy. Relations industrielles / Industrial Relations, 6(3), 86-89. https://doi.org/10.7202/1023225ar

Tous droits réservés @ Département des relations industrielles de l’Université Laval, 1951
Ce document est protégé par la loi sur le droit d'auteur. L'utilisation des services d'Érudit (y compris la reproduction) est assujettie à sa politique d'utilisation que vous pouvez consulter en ligne.

https://apropos.erudit.org/fr/usagers/politique-dutilisation/ 
achievements, and their enforcement led to the proper operation and to the efficiency of the apprenticeship centers.

It is to be hoped that, with the constant improvement of these methods, our apprenticeship system will always be in a position to answer the ever-increasing needs of the industry in our province.

\section{A World-wide Economy}

by Fr. Lionel Moreau

The problems of Political Economy, production and distribution of goods, can no longer be limited to class problems or even to national problems. They are problems which present themselves on a world-wide scale. Such is the principal statement that His Holiness Pope Pius XII made last June 3rd, to the International Congress of Social Studies and of the International Christian Social Union.

After having thus outlined the problem of balancing production and consumption within the world economy, His Holiness, continuing his teachings of Summi Pontificatus and his Christmas speeches on Peace, counts on the universal fellowship of the great human family and makes appeal to the " combination of all good people"; "Away with the selfish preoccupations of nations and classes which can hinder, even in the smallest way, a work loyally undertaken and vigorously carried out - in the cooperation of all forces and all possibilities throughout the world, for the aid of all initiatives, and all efforts by individuals and private groups, with the universal collaboration of peoples and states, each one making its respective contribution of wealth in raw materials, capital and labour".

In our time, serious studies are undertaken by economists to put the capitalist system back in operation again.

As the Reverend Father Lévesque notes " on the doctrinal plane, the majority of individuals, as much in the United States as in Canada, continue to believe in liberalism and in the economic system which embodies it. But their faith has undergone an evolution, because their adhesion has ceased to be a complete one to become conditional. Liberal capitalism is no longer regarded as the only possible system and the phenomena to which it gives rise, such as depressions, are no longer considered inevitable. ${ }_{1}$

This revolution on the doctrinal plane is the logical consequence of a revolution on the economic theory plane. Let us mention the principles brought out in the "General Theory of Employment, Interest and Money" by Lord Keynes to which refer the Fair Deal of Truman and the similar plan applied in Canada. Furthermore, the Marshall plan, the gifts of Canada to European countries, the Colombo plan proposed recently by the United States to help Asia, have no doubt a most commendable humanitarian aim but come also within this capitalistic context.

The capitalist system had to renew itself or disappear. It has tried to promote social progress by extending its programme of economic stability. Capitalism is going through different phases, so much so that one would believe to be in the presence of new doctrines with the New Deal and the Fair Deal. We are evident-

(1) Réalisme économique et progrès social, Semaines sociales de France, Lille, 1949 , p. 90. 
ly not discussing the planned economy which has taken hold of the United States since the beginning of the Korean War.

The statisticians of the U.N.O. have made a comparative study of the wealth of various countries for 1949. Seventy countries which represent $90 \%$ of the world's population and possess $95 \%$ of the world's revenue, have had a national income of $\$ 515$ billions. The United States alone have had $\$ 216$ billions, which gives a revenue per person of $\$ 1,453$. Canada comes second with $\$ 870$ per person. The following countries are: New Zealand (856), Switzerland (849), Sweden (780), Great Britain (773), Denmark (689), Australia (679), Norway (587), Belgium (582), etc. Russia only appears in the 23rd place with an income of $\$ 308$ per person. China has an average revenue of $\$ 27$ per person. The countries which do not have an average revenue over $\$ 40$ per person for 1949 are the following : Indonesia (25), China (27), Southern Korea (35), Burma and Siam (36), Ethiopia and Liberia (38), Ecuador, Haiti, Arabia and Yemen (40).

Here is an idea of the industrial power of the United States in $\mathbf{1 9 5 0 .}$ This country manufactured last year, by month, 500,000 refrigerators, 450,000 washing-machines, 950,000 radios, 550,000 television sets, 4 million men's suits, 52 million pairs of nylon stockings, 700,000 cars and 110,000 trucks. There were 13 or 14 million more workers employed than in 1939 and they produced twice as much steel as at the beginning of the last Great War.

In spite of the fact that the standard of living is the highest in the world in the countries where the large corporations are most prevalent, we must say that capitalism, in regard to the ideal principle of social progress, is far from having produced its most perfect results.
Economic prosperity and social progress require in an industrialized country that the national income be stable and maximum, that it be divided equitably between all the factors of production of this national revenue and that the best use of individual income be guaranteed.

An author (J. A. Estey) states that from 1796 to 1920 the United States have known 14 cycles of an average duration of 9 years, and that the ratio between the years of prosperity and those of depression has been 1.6 to 1. Another (Moulton) says that the productive resources of the United States have not been utilized at more than $80 \%$ from 1925 to 1929 . Public inquiries on trusts and cartels reveal that there exists an unfair distribution of wealth or national revenue among the various factors of production. Finally, publicity which should inform the consumers on the qualities of the products put on sale to satisfy their needs, forms their taste in a prejudicial way, creates in them new needs for products less useful if not decidedly harmful, but which are easier to produce in series. In the final analysis, the classes which receive the least important share of the national revenue do not use it in a way to obtain the maximum of well-being. ${ }^{2}$

Faced with these problems, the capitalist countries have turned more and more towards a modified liberal economy. The programme of the New Deal is an attempt at a planned economy based on monetary methods. But we know to-day that if monetary methods are absolutely necessary to business recovery, after a period of depression, they cannot, however, bring prosperity alone. There must be a certain balance between the "investments" and "consumption expenditures".

(2) Summary of the statement of Reverend Father Lévesque, in the course quoted above. 
The State, say modern rulers and capitalists, must intervene to maintain this balance. In a period of inflation, its funtion is to withdraw large sums of money by taxation; in a period of depression, it is to diminish greatly the taxes, and, furthermore, to undertake public works to increase the "investments" and reduce unemployment. The State must also arrange by its taxation and social security measures to better redistribute the national wealth between the different classes of society. It will do so by progressive rates of income tax on one side and measures of social assistance and insurance on the other.

Since depressions follow too great or too sudden economic variations, the State will have the duty of compensating these fluctuations coming from the private sector of the national economy by the setting up of its own budget. The wisdom of its rulers will be shown by the proper choice of the time when it may most efficiently intervene in the logical way we have just described.

Has capitalism found its way? Is it able to apply without compromise St. Thomas d'Aquin's principle of the social destiny of privately possessed wealth? Is it able to eliminate the cyclical depressions? We do not believe so. First of all, we reply in appealing to the facts. In the Autumn of 1949, the obvious signs of a depression in Canada and the United States appeared. All through the Winter, the number of unemployed increased continually. We would now be under the effects of this depression if once more peace production had not been directed toward war production from 1950 on, in order to meet the necessities of the Korean war and the re-arming of western Europe as well as the countries of North America.

Furthermore, these attempts at reform are inspired too much by capitalist and national preoccupations to bring the proper solution to the present world crisis. "Men have only exaggerated mass production and exploitation to the point of exhausting all resources above, below or on the surface of earth. Men have only too cruelly sacrificed for these attempts the rural populations and economies," as His Holiness says in his speech of June 2rd, 1950. Mr. Pierre Bayart ${ }^{3}$ who analyzes this speech of His Holiness Pius XII, continues the reasoning thus: "The true wealth of a people cannot be measured by purely quantitative standards, but by the sane social structure of a community of which the Family is at the base."

These attempts at reform are still too selfish. They forget the necessary renewal and expansion of the spirit of justice, brotherhood and peace.

We could make these statements clearer. We could add other reasons to show that capitalism must renew itself or disappear, but in a direction entirely different from that in which it is engaged instinctively by selfpreservation. This new direction which world economy must take has been clearly presented to the world by His Holiness Pius XII in his speech of June 3rd, 1950. We would like to present to our readers one of the best analyses of this speech that we have read : " Réorganisation de l'économie mondiale et co-gestion dans l'entreprise." (Re-organization of world economy and co-managment of the enterprise), by $\mathbf{M r}$. Pierre Bayart, Professor in the $\mathbf{F a}$ culty of Law at Lille, France.

Mr. Bayart notes appropriately that this speech of the Holy Father does not deal only with the problem of comanagement in the enterprise, but

(3) Re-organization of world economy and co-management of the enterprise, analysis of the Speech of His Holiness, Pius XII, on June 3rd, to the International Congress of Social Studies and of The International Christian Social Union, by Pierre Bayart, professor at the Faculty of Law, Lille, France. 
primarily with the problem of unemployment which in its threatening and permanent menace "risks to starve thousands of men, the immense multitude of unfortunates. .." "This problem of periodic unemployment," says Mr. Bayart "is the crucial problem of capitalism, and more exactly of an economic system founded on the dynamic development of technical progress, which by the movement it imparts to the economic activity, necessarily initiates, in its forward progress, the variations, fluctuations and depressions, cyclical or not." Here is the summary of the Papal conception in this speech of June 3rd as presented by Mr. Bavart :

"The rejection of the "mechanism of social organizations in contradiction with the order established by God," i.e. the integral planning of the soviet system;

The rejection of a pure and simple return to a liberalism condemned by the Church and exceeded by the facts, which, to re-establish a normal economy, would depend only on the mechanism of the laws of the market;

The warning against the deformation of social security by a socialistic conception which would place « trust in an all-providing state (un étatprovidence) charged with providing for each of its subjects, and in every circumstance of life, the right to advance claims which basically cannot be satisfied 》;

The warning against certain conceptions of full employment realized by too artificial formalism;
The primordial necessity, in order to realize this policy of full employment and the first of social securities: that of work, to organize, at the very source of the economy, and in avoiding the excesses of a production without bounds, a sane and normal production, " wisely measured according to the needs and to the dignity of men " and arranged around the organic unit basis of society, which is the Family ;

The maintenance, at the basis of the economy, of the private enterprise, with all the concessions corresponding to its social character, but in maintaining nevertheless its private character and in leaving to management the personal responsibility and the control of economic decisions and in safeguarding as much as possible against the double danger of anonymous capitalism and socialization, the soundest portion of the economy - individual and family exploitations ;

The positive declaration, repeated once again, of the primordial necescity of professional organization."

This is the new direction that the Holy Father points out to world economy. $\mathrm{He}$ asks now that "theorists and men of action . . . concentrate their attention upon, making it the focal point of their study . . . on the imminent and permanent threat of unemployment, the most important and urgent problem, that which weighs like a nightmare precisely on these old industrial countries ...."

\section{Toward a Union of Families}

Last April 23rd and 24th, the Department of Industrial Relations of the Faculty of Social Sciences of Laval welcomed in the vast Ballroom of the Chateau Frontenac, nearly five hundred delegates who came from all corners of the Province and from many walks of life: employers, workers, personnel managers, foremen, officers of employers' and workers' associations, representatives of parity committees, moral advisors, government labour officials, representatives of social groups, etc.

For two days, the delegates studied, with the proper attention and 